\title{
AC 2012-3750: STRUCTURED DESIGN APPROACH FOR CONVERTING CLASSROOM COURSES FOR ONLINE DELIVERY
}

\author{
Ms. Mary L. Fletcher, Johns Hopkins University
}

Mary Laurette (Laurie) Fletcher received her B.S. degree in software data management from the University of Maryland and her M.S. in technical management from the Johns Hopkins University Whiting School of Engineering. She has more than 25 years of experience in software data management, technical publications and communications, and proposal management. Her particular areas of expertise include her understanding of the business relationship and contracting between private industry and the U.S. government, and the acquisition and management of Small Business Innovative Research programs. Fletcher is the Vice President of Fraser Technical Consulting, where her responsibilities include services specializing in software data management, proposal management, and technical publications. She was previously employed by Solipsys Corporation (now Raytheon Solipsys), where she held the following positions: Data Management Group Supervisor, Assistant Program Manager for DD(X), and Corporate Proposal Manager. Fletcher is a member of the following organizations: American Association of Engineering Education, American Society for Engineering Management, Society of Technical Communications, Women in Engineering ProActive Network, Society of Vertebrate Paleontology, Wyoming Geological Association, and the Tate Geological Museum Advisory Board. She is also an instructor for the Osher Lifelong Learning Institute at Casper College in the subject of the "History of Mysteries."

\section{Dr. Allan W. Bjerkaas, Johns Hopkins University}

Allan W. Bjerkaas holds a bachelor's degree with a double major in physics and mathematics from the University of North Dakota and a master's degree and a Ph.D. in physics from the University of Illinois, Urbana-Champaign. He joined the Johns Hopkins University Applied Physics Laboratory in 1973 after completing a two-year postdoctoral appointment at the University of Pittsburgh. While at the Applied Physics Laboratory, Bjerkaas was a Project Manager in the Submarine Technology Department and a Group Supervisor in both the Submarine Technology Department and the Research and Technology Development Center. Since the mid-1970s he has taught in the part-time graduate programs that Johns Hopkins has offered for working engineers. He received the Excellence in Teaching Award in 1992. Bjerkaas has been the Chair for the Applied Physics and the Information Systems and Technology programs. In 2001, he became the Associate Dean for the Engineering for Professionals (EP) programs in the Whiting School of Engineering, a position he held full-time after retiring from the Applied Physics Laboratory in Feb. 2005 until he retired from the Whiting School of Engineering in Sept. 2010. He now resides in Fergus Falls, Minn., and continues to teach online courses for EP. He can be reached at bjerkaas@jhu.edu. 


\title{
Structured Design Approach for Converting Classroom Courses for Online Delivery
}

\begin{abstract}
As online courses have proliferated, more and more face-to-face instructors are challenged with the requirement to develop their courses for the online environment. In this paper, a spreadsheet table is described in which each row represents a week, called a module, of the class and each column represents a specific design element, such as learning objectives, learning assessments, resources, lectures, videos, other learning activities, or other design components found in an online course.
\end{abstract}

The process begins with an effort to infer the learning objectives by examining the content and assignments given in the classroom. These are entered into the table. Next the assignments from the classroom are entered in the assessment column and the alignment between learning objectives and assessments is determined followed by adjustments to the learning objectives and assessments to achieve better alignment. The content material that will result in the students achieving the learning objectives is then determined using what can be leveraged from the classroom as well as new material.

The iteration process continues with adjustments to the learning objectives, assessments, and content material until the instructor is satisfied that the course is both well aligned across a module as well as sequentially from week to week. This spreadsheet table then becomes the final overall detailed description of the course and serves as a starting point for design tune-up activities each time the course is taught.

\section{Introduction}

There is a two-fold challenge in converting face-to-face (classroom) courses for online delivery. The first is the overall task of systematically translating a class to an online environment. But there is rarely a one-to-one correspondence in the translation, often because the face-to-face faculty received little-to-no formal training on course design nor had any instructional design support, and therefore resorted to using general pedagogical techniques. So there is the coincidental problem of teaching faculty to redesign existing classes to accommodate the online environment. This is especially important because of the need to offer the students a course that is clearly aligned across the learning modules and through the duration of the semester.

The Johns Hopkins University Engineering for Professionals, Technical Management Program uses a course design matrix (CDM) spreadsheet approach designed by the authors to ensure that all online courses in development have an effective alignment and that applicable assessments are chosen to measure success in achieving the learning objectives.

In this paper, the top-level process of making the transition to an online course will be provided and then the CDM approach will be deconstructed in detail. The iteration of this approach will 
be explained as an ongoing process throughout the life of the course and, finally, necessary elements for training the instructors will be examined.

\section{Top-level Process}

The existing face-to-face material is the basis for starting the breakdown of the course into a matrix. While the intention is to reuse as much material as possible, it is important to approach this process with a willingness to let go of material that does not work well in an online environment (e.g., free-ranging classroom discussions).

It should be possible to reverse-engineer learning objectives from the existing course material (and if that is not possible, there is a fundamental disconnect that needs to be addressed before progressing any further). A good framework, driven by well-crafted learning objectives, is key to populating this CDM with the course content.

After the course learning objectives have been established, it is important to design appropriate assessments (discussions, papers, presentations, scenarios, tests, etc.) to ensure that the students have understood and can implement the learning objectives.

Only after the learning objectives and assessments have been drafted should the learning materials/learning objects be derived from the face-to-face course or designed for the online course. This ensures that the learning objectives and assessments drive the design of the course and that they are not used instead to adhere to existing materials that may or may not be appropriate for the course.

A basic template for a CDM is provided in Figure 1.

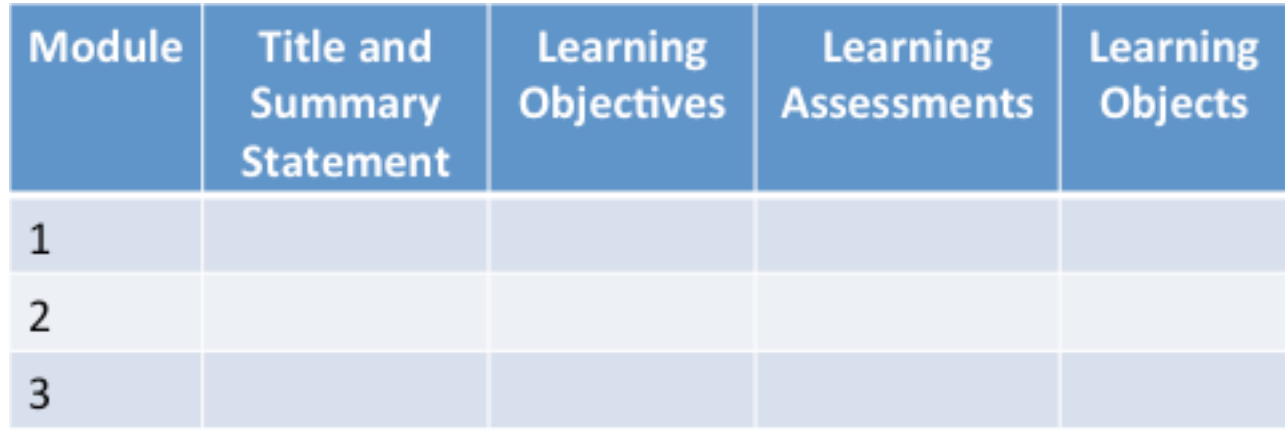

Figure 1. Course Design Matrix (CDM) Template

Once the CDM is populated with these elements, it is important to first align the learning objectives, assessments, and materials across a module and then align the modules with each other. This iterative process may drive a change in the hierarchy of module themes and a reorganization of materials into more associative elements. A basic overview of this process is provided in Figure 2. 


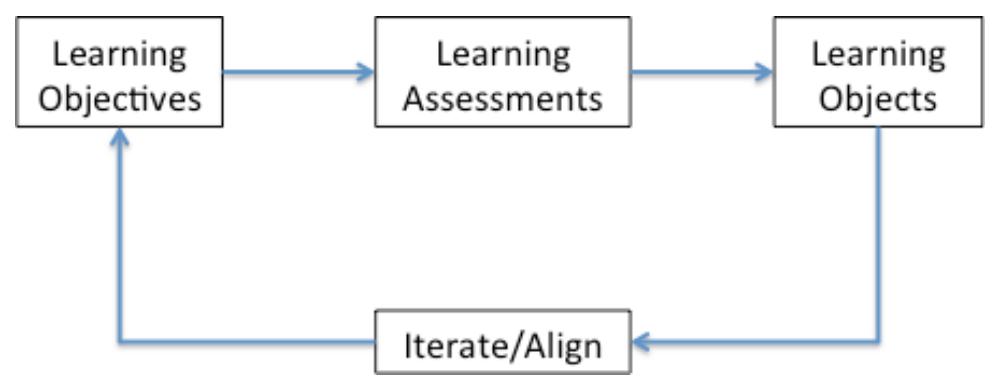

Figure 2. Course Design Process Overview

An important element in course design, both online and face-to-face, is the establishment of a consistent, reliable vocabulary. Bloom's Taxonomy of learning levels ${ }^{1}$ captures the language of learning objectives as expected outcomes of learning, i.e., what students should be able to do after they complete a module.) Because this is such a universal approach to the definition of learning objectives, it is important that instructors have training in the use of Bloom's Taxonomy before embarking on the course design process. Many if not most instructors are already versed in the taxonomy but it is important to ensure that there is training available for those who are not. It is essential to have this vocabulary in course design.

\section{Getting Started}

Before working on the CDM, it is important to get organized:

- Organize lectures in sequence

- Organize classroom activities in sequence

- Organize assignments, projects and exams

- Arrange materials into tentative weekly modules

Module Title, Summary Statement

The module title provides the main theme(s) for the module and the summary statement provides a sentence about each topic covered in the module. A sample module title and summary statement are provided in Figure 3. 


\begin{tabular}{|c|c|}
\hline $\begin{array}{l}\text { Modules, Module Theme } \\
\text { (Organizational Emphasis) }\end{array}$ & Summary Statement \\
\hline \multirow{2}{*}{$\begin{array}{c}1 \text { - Fundamentals of Technical } \\
\text { Communications } \\
\text { (General) }\end{array}$} & $\begin{array}{l}\text { Where it all starts - Technical Communications and } \\
\text { Writing }\end{array}$ \\
\hline & $\begin{array}{l}\text { Analyzing the communications context of an } \\
\text { audience; knowing your audience }\end{array}$ \\
\hline \multirow{3}{*}{$\begin{array}{c}\text { - Situational Awareness and Barriers } \\
\text { to Communication } \\
\text { (General) }\end{array}$} & Situational analysis (one size does not fit all) \\
\hline & $\begin{array}{l}\text { Barriers to communication; practicalities of } \\
\text { communication - why so much is subjective }\end{array}$ \\
\hline & Turn mistakes into learning opportunities \\
\hline \multirow{3}{*}{$\begin{array}{c}\text { 3 - Corporate Communication and } \\
\text { Knowledge Management } \\
\text { (Executive) }\end{array}$} & Top-down communication \\
\hline & Corporate informational structure \\
\hline & Knowledge management and archival issues \\
\hline
\end{tabular}

Figure 3. Sample Module Titles and Summary Statements ${ }^{2}$

\section{Learning Objectives}

When reverse-engineering learning objectives, it is important to ask "what were the students expected to learn in each academic week?"

Here are some clues:

- What were the assignments and projects about?

- What did the exams test?

- What were the lecture topics?

The language of learning objectives is codified in Bloom's Taxonomy. All learning objectives should adhere to the use of the Bloom's verbs and the hierarchy should be applied to the academic level of the course. It should also accurately represent the spread of the activities in the course. More than one course has been redesigned and learning objectives recrafted because of the internal awareness provided by Bloom's Taxonomy.

It is important to align the learning objectives in logical sequence within each module and then, when going through subsequent iterations, ensure that objectives are in logical sequence from module to module. Finally, it is important to add or delete objectives as needed. If they don't work, throw them out.

A sample CDM with learning objectives added is provided in Figure 4. 


\begin{tabular}{|c|c|c|}
\hline Modules, Module Theme (Organizational Emphasis) & \begin{tabular}{|l|} 
Summary Statement \\
\end{tabular} & \begin{tabular}{|l|} 
Learning Objective(s) \\
\end{tabular} \\
\hline \multirow[t]{2}{*}{$\begin{array}{c}1 \text { - Fundamentals of Technical Communications } \\
\text { (General) }\end{array}$} & Where it all starts - Technical Communications and Writing & $\begin{array}{l}\text { 1. Explain the reasons that effective communications } \\
\text { begin with good writing. }\end{array}$ \\
\hline & $\begin{array}{l}\text { Analyzing the communications context of an audience; } \\
\text { knowing your audience }\end{array}$ & $\begin{array}{l}\text { 2. Determine the makeup of the audience. } \\
\text { 3. Analyze their technical level of understanding. } \\
\text { 4. Identify the audience's inherent vocabulary. } \\
\text { 5. Clarify/focus the message and/or the action you want } \\
\text { to have as a result. }\end{array}$ \\
\hline \multirow[t]{3}{*}{$\begin{array}{l}\text { 2- Situational Awareness and Barriers to Communication } \\
\text { (General) }\end{array}$} & Situational analysis (one size does not fit all) & $\begin{array}{l}\text { 1. Analyze a communication context, including the } \\
\text { audience characteristics and the message (and desired } \\
\text { outcome) [from Module 1] to determine what additional } \\
\text { information is needed by the audience. } \\
\text { 2. Develop an optimal communications methodology } \\
\text { based on the previous analysis. } \\
\text { 3. Design and describe the communication. }\end{array}$ \\
\hline & $\begin{array}{l}\text { Barriers to communication; practicalities of } \\
\text { communication - why so much is subjective }\end{array}$ & $\begin{array}{l}\text { 4. Identify the barriers to effective communication. } \\
\text { 5. Describe the consequences if the barriers are not } \\
\text { addressed. } \\
\text { 6. Develop strategies to reduce the impact of the barriers. }\end{array}$ \\
\hline & Turn mistakes into learning opportunities & $\begin{array}{l}\text { 7. Assess the effectiveness of a communication event. } \\
\text { 8. Identify communications shortcomings. } \\
\text { 9. Develop means for remediation. }\end{array}$ \\
\hline \multirow[t]{4}{*}{$\begin{array}{c}\text { - Corporate Communication and Knowledge } \\
\text { Management } \\
\text { (Executive) }\end{array}$} & Top-down communication & $\begin{array}{l}\text { 1. Describe the communication responsibilities of upper } \\
\text { level management. } \\
\text { 2. Evaluate the methods typically used by upper-level } \\
\text { management to communicate. }\end{array}$ \\
\hline & Corporate informational structure & $\begin{array}{l}\text { 3. Describe procedures to put into place to facilitate } \\
\text { corporate information transfer up and down and across } \\
\text { the organization. }\end{array}$ \\
\hline & \multirow[t]{2}{*}{ Knowledge management and archival issues } & 4. Evaluate the procedures typically used in such an \\
\hline & & $\begin{array}{l}\text { 5. Describe the elements of organizational knowledge } \\
\text { management. } \\
6 \text {. Develop a plan to maintain archives. }\end{array}$ \\
\hline
\end{tabular}

Figure 4. Sample CDM with Learning Objectives

\section{Learning Assessments}

In the classroom, there is sometimes more emphasis on formative learning assessments, i.e., the assessments that serve as a barometer for how much is being understood at that moment. Examples of such assessments are discussions that are not graded, practice activities (again, ungraded), and other such interactions. In the online environment, these activities can still take place in the form of office hours discussions and ensuring that collaboration tools are available for practice, but they need to be understood to be completely separate from summative assessments, which are graded and serve as a quantifiable measure of learning. When we talk about assessments for online courses, we are primarily talking about summative assessments. It should be noted that the relatively mature students in our graduate courses find formative assessments annoying and would rather be graded on all that they do, no matter what the risk of a potentially lower grade may be because no preliminary formative assessment results were available to them.

When moving from assessments in a classroom setting to online assessments, it is important to first align assessments from the classroom that relate to the new list of learning objectives that are now populating the CDM. It will likely be necessary to design additional learning assessments to cover the learning objectives.

Assessments that work well in an online setting may include:

- Asynchronous web discussions

- Problems

- Scenarios

- Essay topics

- Research papers 
- Presentations (using collaborative media or meeting applications)

The assessments to go with the learning objectives that were provided in Figure 4 are shown in Figure 5.

\begin{tabular}{|c|c|c|}
\hline $\begin{array}{c}\text { Modules, Module Theme } \\
\text { (Organizational } \\
\text { Emphasis) }\end{array}$ & Learning Objective(s) & $\begin{array}{c}\text { Assessments } \\
\text { (for full detail, see "Assessments" tab) }\end{array}$ \\
\hline $\begin{array}{l}1 \text { - Fundamentals of } \\
\text { Technical Communications }\end{array}$ & $\begin{array}{l}\text { 1. Explain the reasons that effective communications } \\
\text { begin with good writing. } \\
2 . \text { Determine the makeup of the audience. } \\
\text { 3. Analyze their technical level of understanding. } \\
\text { 4. Identify the audience's inherent vocabulary. } \\
5 \text {. Clarify/focus the message and/or the action you want } \\
\text { to have as a result. }\end{array}$ & $\begin{array}{l}\text { W1 - Website Discussion } 1 \text { - (Not everyone has their } \\
\text { textbook on the first week so we'll be posting some } \\
\text { general questions for this week's discussions.) Please tell } \\
\text { us a little about yourself, e.g., where you grew up, where } \\
\text { you went to school, where you live now, where you work, } \\
\text { what do you like to do for fun, etc. Anything you'd like for } \\
\text { us to know about you. Then, what is your major, how } \\
\text { many classes have you taken before this, and why are you } \\
\text { in this program? And please post a picture (you can do } \\
\text { this in the Website Discussions tool under "My Profile"), if } \\
\text { you're comfortable with doing so - it really helps to be } \\
\text { able to picture the other people when you're involved in } \\
\text { discussions. }\end{array}$ \\
\hline $\begin{array}{c}\text { - Situational Awareness } \\
\text { and Barriers to } \\
\text { Communication }\end{array}$ & $\begin{array}{l}\text { 1. Analyze a communication context, including the } \\
\text { audience characteristics and the message (and desired } \\
\text { outcome) [from Module 1] to determine what additional } \\
\text { information is needed by the audience. } \\
\text { 2. Develop an optimal communications methodology } \\
\text { based on the previous analysis. } \\
\text { 3. Design and describe the communication. } \\
\text { 4. Identify the barriers to effective communication. } \\
\text { 5. Describe the consequences if the barriers are not } \\
\text { addressed. } \\
\text { 6. Develop strategies to reduce the impact of the barriers. } \\
\text { 7. Assess the effectiveness of a communication event. } \\
\text { 8. Identify communications shortcomings. } \\
\text { 9. Develop means for remediation. }\end{array}$ & $\begin{array}{l}\text { W2 - Website Discussion } \mathbf{2} \text { - [Communications } \\
\text { Barriers] You are a five-year employee of AVI and have } \\
\text { just transferred from the System Test Group to the } \\
\text { Systems Group. You are the new roommate of Lynne } \\
\text { Baron, a mathematician and systems engineer, who you } \\
\text { know casually from working at AVI. You have been put } \\
\text { together because you will be working on some of the } \\
\text { same projects. .... } \\
\mathbf{S 1} \text { - Scenario } \mathbf{1} \text {-... Write a } 1000 \text {-word plan for how you } \\
\text { will assess the audience, clarify your message, and choose } \\
\text { a methodology for an oral presentation to the AVI } \\
\text { Management Committee. Provide as much rationale for } \\
\text { your plan as will fit into the } 1000 \text { word limit. } \\
\text { E1 - Essay } \mathbf{1} \text { - (two-week assign) Essay } 1 \text { - Research and } \\
\text { write a } 2000 \text {-word paper on medlating the challenges in } \\
\text { communications with virtual (non-co-located) teams and } \\
\text { then discuss the benefits... }\end{array}$ \\
\hline $\begin{array}{c}3 \text { - Corporate } \\
\text { Communication and } \\
\text { Knowledge Management }\end{array}$ & 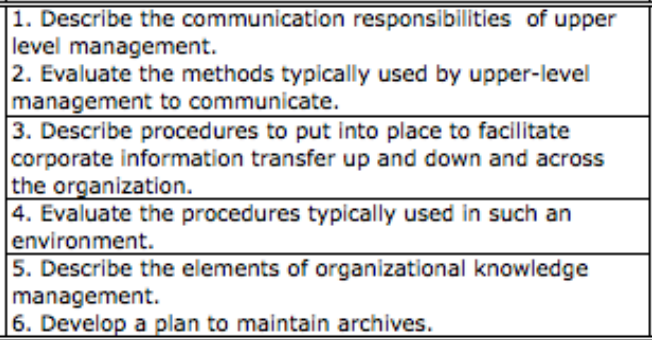 & $\begin{array}{l}\text { W3 - Website Discussion } 3 \text { - Describe in simple terms } \\
\text { communications procedures in place in your real work } \\
\text { environment (not AVI); explain any deficiencies you have } \\
\text { observed, and suggest ways to improve the procedures. } \\
\text { Please feel free to change names to disguise people or } \\
\text { organizations. Comment constructively on at least one } \\
\text { other classmate's approach. } \\
\mathbf{5 2} \text { - Scenario } \mathbf{2} \text { - As an AVI department head, write a } \\
500-600 \text {-word memo to all employees describing the new } \\
\text { archiving policy and any new reporting guidelines that go } \\
\text { with it... }\end{array}$ \\
\hline
\end{tabular}

Figure 5. Learning Objectives and Assessments Example

\section{Learning Objects}

Learning objects will be as diverse as the courses being translated from the classroom to the online environment. They may include lectures, videos, demonstrations, websites, and will almost certainly include textbooks and/or outside reading assignments. The most important aspect in designing learning objects is, of course, to ensure that they are appropriate for the learning objectives and the assessments. General guidelines for designing learning objects include:

- Break up lectures into 10-15 minute segments for recording 
○ This is called "chunking" and it is part of a principle of communications that identifies the amount of information a person can best absorb in any one-time interval.

- Replace lectures with readings where possible

$\circ$ It is important to assume some independent ability of online students in managing their learning objects and their time.

- Use video learning objects where possible.

- Align the objects with the learning objectives and assessments

Ask this question: "Will the learning object help the student achieve the learning objectives as measured by the assessments?"

The learning objectives and assessments from Figure 5 are now shown with the learning objects for these modules in Figure 6.

\begin{tabular}{|c|c|c|c|c|c|}
\hline Objectives & Assessments & \multicolumn{4}{|c|}{ Learning Objects } \\
\hline Learning Objective(s) & $\begin{array}{c}\text { Assessments } \\
\text { (for full detail, see "Assessments" tab) }\end{array}$ & Learning Method & Video Description & $\begin{array}{l}\text { MIT Guide to } \\
\text { Science and } \\
\text { Engineering } \\
\text { Communication } \\
\text { (Second Edition) }\end{array}$ & \begin{tabular}{|c|} 
Human Side of \\
Managing \\
Technological \\
Innovation (Second \\
Edition)
\end{tabular} \\
\hline $\begin{array}{l}\text { 1. Explain the reasons that effective } \\
\text { communications begin with good writing. }\end{array}$ & $\begin{array}{l}\text { W1 - Website Discussion } 1 \text { - Tell } \\
\text { us about yourself. }\end{array}$ & $\begin{array}{l}\text { Lecture "Course Introduction - The } \\
\text { Evolution of Communication" } \\
\text { Lecture "Technical Communications } \\
\text { Overview" } \\
\text { Lecture - video introductions }\end{array}$ & $\begin{array}{l}\text { Adobe Systems video - Evolution of } \\
\text { Communication } \\
\text { and } \\
\text { The Future of Communication }\end{array}$ & 1 Writing and Work & $\begin{array}{c}4 \text { Managing Creative } \\
\text { Professionals }\end{array}$ \\
\hline $\begin{array}{l}\text { 2. Determine the makeup of the audience. } \\
\text { 3. Analyze their technical level of } \\
\text { understanding. } \\
\text { 4. Identify the audience's inherent } \\
\text { vocabulary. } \\
\text { 5. Clarify/focus the message and/or the } \\
\text { action you want to have as a result. }\end{array}$ & & $\begin{array}{l}\text { Lecture "Communication - The Process" } \\
\text { Lecture "Communication - The Message and } \\
\text { the Receiver" }\end{array}$ & Effective Writing Skills & $\begin{array}{l}3 \text { Your Audience and } \\
\text { Aims }\end{array}$ & \\
\hline $\begin{array}{l}\text { 1. Analyze a communication context, } \\
\text { including the audience characteristics and } \\
\text { the message (and desired outcome) [from } \\
\text { Module 1] to determine what adiditional } \\
\text { information is needed by the audience. } \\
\text { 2. Develop an optimal communications } \\
\text { methoodology based on the previous } \\
\text { analysis. } \\
\text { 3. Design and describe the communication. }\end{array}$ & $\begin{array}{l}\text { W2 - Website Discussion 2 - } \\
\text { [Communication barriers] } \\
\text { S1 - Scenario } 1 \text { - ...Write a 1000- } \\
\text { word plan for how you will assess } \\
\text { the audience, clarifify your message, } \\
\text { and choose a methodology for an } \\
\text { oral presentation to the AVI } \\
\text { Management Committee. Provide } \\
\text { as much rationale for your plan as }\end{array}$ & $\begin{array}{l}\text { Lecture (video introduction) "Situational } \\
\text { Awareness" } \\
\text { Lecture (video introduction) "Detailed } \\
\text { Design" }\end{array}$ & $\begin{array}{l}\begin{array}{l}\text { Typography about language by Ronnie } \\
\text { Bruce }\end{array} \\
\text { Get Prepared to Present Well }\end{array}$ & $\begin{array}{c}3 \text { Your Audience and } \\
\text { Alms }\end{array}$ & \\
\hline $\begin{array}{l}\text { 4. Identify the barriers to effective } \\
\text { communication. } \\
\text { 5. Describe the consequences if the barriers } \\
\text { are not addressed. } \\
\text { 6. Develop strategies to reduce the impact } \\
\text { of the barriers. }\end{array}$ & $\begin{array}{l}\text { will fit into the } 1000 \text { word limit. } \\
\text { E1 - Essay } 1 \text { - (two-week assign) } \\
\text { Essay 1-Research and write a 2000- } \\
\text { word paper on mediating the } \\
\text { challenges in communications with } \\
\text { virtual (non-co-located) teams and }\end{array}$ & $\begin{array}{l}\text { Lecture (video introduction) } \\
\text { "Communication Barriers" }\end{array}$ & $\begin{array}{l}\text { Virtual Teamwork, Leadership, and } \\
\text { Meetings }\end{array}$ & & 24 Virtual Teams \\
\hline $\begin{array}{l}\text { 7. Assess the effectiveness of a } \\
\text { communication event. } \\
\text { 8. Identify communications shortcomings. } \\
\text { 9. Develop means for remediation. }\end{array}$ & then discuss the benefits... & Lecture "Communication Mistakes" & & & \\
\hline $\begin{array}{l}\text { 1. Describe the communication } \\
\text { responsibilities of upper level } \\
\text { management. } \\
\text { 2. Evaluate the methods typically used by } \\
\text { upper-level management to communicate. }\end{array}$ & $\begin{array}{l}\text { W3 - Website Discussion 3 - } \\
\text { Describe in simple terms } \\
\text { communications procedures in place } \\
\text { in your real work environment (not } \\
\text { AVI)... } \\
\text { S2 - Scenario 2 - As an AVI }\end{array}$ & \begin{tabular}{|l}
$\begin{array}{l}\text { Lecture (video introduction) "Intro to } \\
\text { Leadershift" }\end{array}$ \\
\end{tabular} & Joel Barker & $\begin{array}{l}10 \text { Memos, Letters, } \\
\text { Electronic Mail (14 } \\
\text { pages } w / \text { many } \\
\text { figures) }\end{array}$ & $\begin{array}{l}10 \text { Beyond the } \\
\text { Charismatic Leader: } \\
\text { Leadership and } \\
\text { Organizational } \\
\text { Change } \\
\text { (15 pages) } \\
\end{array}$ \\
\hline $\begin{array}{l}\text { 3. Describe procedures to put into place to } \\
\text { facilitate corporate information transfer up } \\
\text { and down and across the organization. }\end{array}$ & $\begin{array}{l}\text { department head, write a } 500-600- \\
\text { word memo to all employees } \\
\text { describing the new archiving policy }\end{array}$ & $\begin{array}{l}\text { Lecture (video introduction) "Employee } \\
\text { Communications" }\end{array}$ & $\begin{array}{l}\text { Strategic Messaging and Employee } \\
\text { Communications }\end{array}$ & & \\
\hline $\begin{array}{l}\text { 4. Evaluate the procedures typically used in } \\
\text { such an environment. }\end{array}$ & $\begin{array}{l}\text { and any new reporting guidelines } \\
\text { that go with it... }\end{array}$ & $\begin{array}{l}\text { Lecture (video introduction) "Leadership } \\
\text { Communications" }\end{array}$ & $\begin{array}{l}\text { Five Tips for Leadership } \\
\text { Communications }\end{array}$ & & \\
\hline $\begin{array}{l}\text { 5. Describe the elements of organizational } \\
\text { knowledge management. } \\
\text { 6. Develop a plan to maintain archives. }\end{array}$ & & $\begin{array}{l}\text { Lecture (video introduction) "Knowledge } \\
\text { Management and Archival Issues" }\end{array}$ & $\begin{array}{l}\text { What You Need to Know About } \\
\text { Archiving, Data Retention, and } \\
\text { Backups Part } 1 \\
\text { What You Need to Know About } \\
\text { Archiving, Data Retention, and } \\
\text { Backups Part } 2\end{array}$ & & $\begin{array}{l}28 \text { Why Information } \\
\text { Technology Inspire } \\
\text { but Cannot Deliver } \\
\text { Knowledge } \\
\text { Management } \\
\text { (11 pages) }\end{array}$ \\
\hline
\end{tabular}

Figure 6. The Application of Learning Objects

The Iterative Process

It is important to feel that the converted online course is complete, effective, and applicable. This may mean several iterations of the process of examining objectives, assessments, and learning objects to ensure that they are aligned across modules and down the length of the course. Here are some things to consider in this iterative process: 
- Review learning objectives for alignment

- Review assessments for alignment and completeness

- Review learning objects for relevance, completeness, and alignment

- Optimize learning objects for effectiveness

- At all times, think of the students, the expectations for their learning, and their ability to apply what they have learned.

\section{A Final Word about Instructor Training}

It is very important that an effective training program in the fundamentals of good pedagogical design be provided to faculty who are responsible for the classroom-to-online conversion. These include good learning objective design, a working knowledge of formative and summative assessment design and use in a course, as well as some orientation on all the excellent sources of learning object materials, including all the free material available on the web from other instructors around the country and the world.

Comprehensive training should also be provided on how to conduct good interactive segments during the online course, as well as training in the use of the online course management system used by the instructors' school.

\section{Conclusion}

Converting face-to-face classes to an online environment is not a straightforward or insignificant task. At all stages of the development process, it is important to examine what worked in the classroom and evaluate whether or not it will work online. And if aspects of a face-to-face class don't work for an online class, do you throw them out or reconfigure them? Having sound learning objectives will help with that evaluation. It is natural to have an attachment to the material that has worked so well for years and feels so comfortable. But it may be necessary to give some of that up if it doesn't work online. But the good news is that this necessary examination of course materials ensures a fresh look at all aspects of a course and may yield improvements in the face-to-face class as well as the online class. The CDM approach should help engineering instructors keep the systematic design process in view all during the development process.

It is also a good idea to keep the matrix handy as the semester unfolds, especially when the online class is fairly new, and to keep it updated as it becomes clear what is working and what is not working as well as expected. This will help ensure that the course structure continues to be a flexible and responsive entity.

An example of the completed CDM with the first three modules of a semester is provided in Figure 7. 


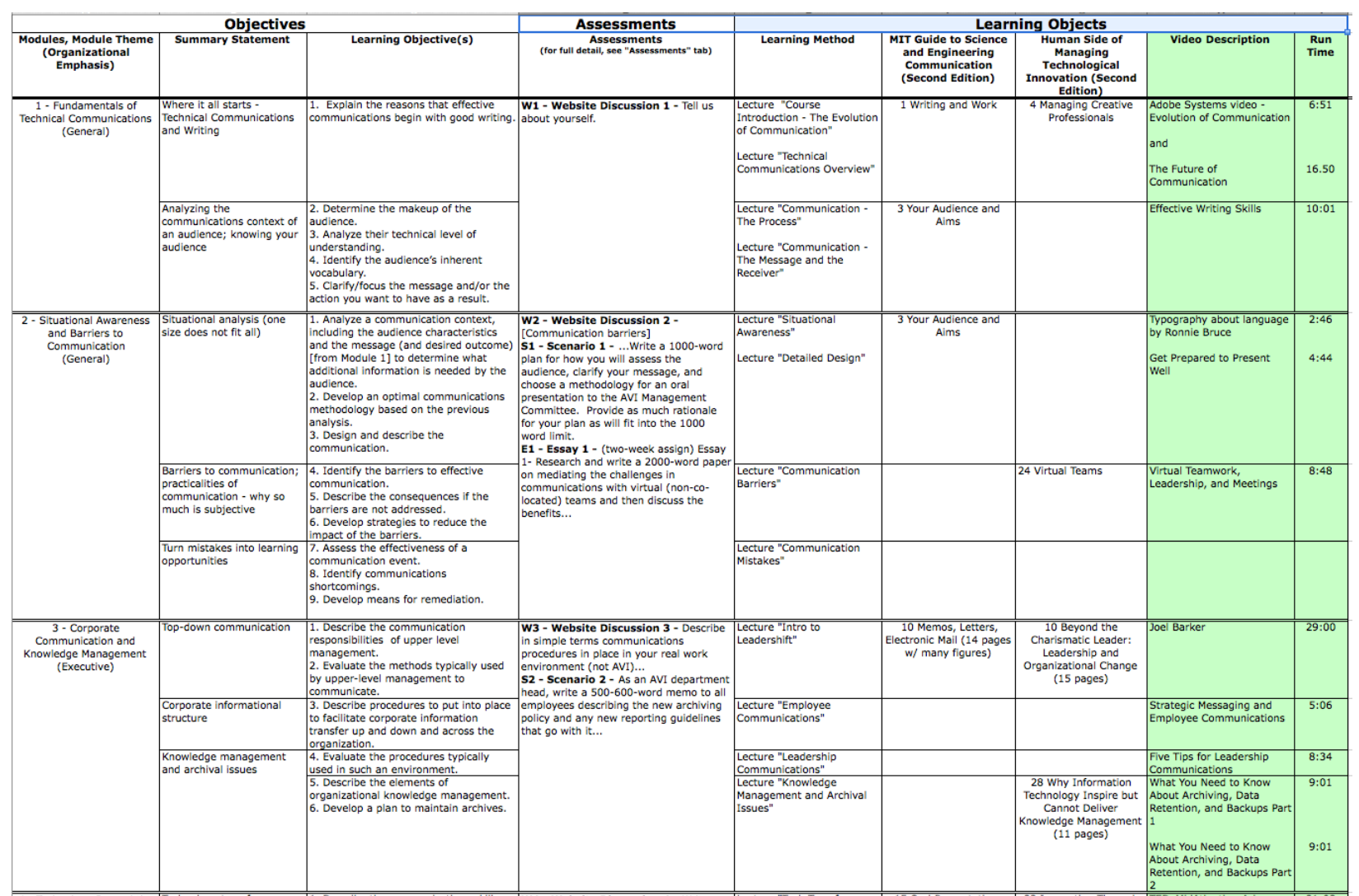

Figure 7. Completed Course Matrix

\section{References}

1 http://www.odu.edu/educ/roverbau/Bloom/blooms taxonomy.htm

2 From The Johns Hopkins University Engineering for Professionals, Management in Technical Organizations course 